\title{
Still, Moving: Reflecting on All This Can Happen
}

Kyra Norman

All This Can Happen is a 50-minute film created by choreographer Siobhan Davies and director David Hinton. Arising from the artists' shared fascination with the work of Etienne-Jules Marey and Eadweard Muybridge, ${ }^{1}$ the film is entirely composed from still and moving images taken from the early days of photography and filmmaking. An almost overwhelming array of visual material drawn from several different archives across different countries, All This Can Happen is arranged around a single narrative thread adapted from Swiss writer Robert Walser's 1917 novella The Walk, narrated by John Heffernan, and supported by a responsive, entrancing soundtrack by Chu-Li Shewring.

Derived as it is from images made in the early twentieth century, All This Can Happen brings into focus a more recent shift in our perceptions of photography and film that began around the end of that century and that is still unfolding: that, as dance-trained filmmaker Miranda Pennell has observed, "as media began to converge and fragment, what had once been understood as the essential and distinct powers of still and moving images, particularly their relationship to time, began to fragment." ${ }^{2}$ In Volume Two of The International Journal of Screendance, Pennell responded to film theorist Laura Mulvey's writing on stillness and the moving image, observing that the "fascination with halting, delaying and repeating movement" that Mulvey discusses "surely describes the curiosity, pleasure and drive of the choreographic impulse." ${ }^{3} \mathrm{All}$ This Can Happen balances the telling of Walser's story with a deep investigation of the choreographic impulse that Pennell considers and the potential of the screen as a space for choreographic inquiry.

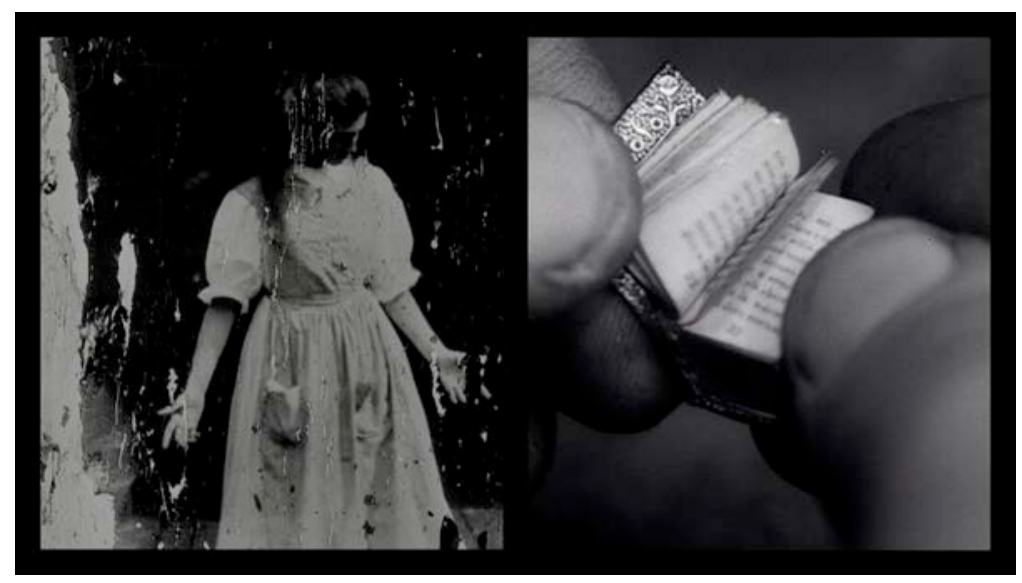

Figure1:

"Alice in Wonderland" still from All This Can Happen, courtesy of BFI National Archive 


\section{A continuity of connection}

The opening image of All This Can Happen is rich with texture. A man, lying in bed, stares back at us. Our engagement with this image in terms of movement comes more from our eye being drawn to the flickering light and shade-the difference in marks and scratches between each still image creating a dappled, frenetic effect as they run in sequence- than a direct response to the body on screen: the movement of the man's head is barely perceptible, seeming indeed, perhaps, a trick of the light. The shifting areas of light and shade render the man more and less visible, before the screen fades to a cloudy white. The man re-emerges from the cloud, his movement a jerky flicker, and the screen then splits into two, the left-hand portion showing an explosion on a hillside, disappearing into cloudy white smoke as, in the right hand portion, a soldier slides down the bank. Over the next fifty minutes the screen space continues to be filled with near-constant motion, at each moment offering several layers of information and inviting us to make connections between images.

The sheer volume of information with which we are presented ensures that any meaning we derive is as elusive and agile as choreography must be. As William Forsythe, in "Choreographic Objects," suggests:

Choreography is a curious and deceptive term. The word itself, like the processes it describes, is elusive, agile, and maddeningly unmanageable. To reduce choreography to a single definition is not to understand the most crucial of its mechanisms: to resist and reform previous conceptions of its definition. ${ }^{4}$

It is testament to the rigorous, original and often playful organization of material in All This Can Happen that it does not become "maddeningly unmanageable" for the viewer. In this, the film aligns with the idea that choreography, as Jonathan Burrows puts it, might be "about making decisions-or about objects placed in relation to each other so that the whole exceeds the sum of the parts-or about a continuity of connection between materials. ${ }^{15}$ Watching All This Can Happen, I felt I was being presented with an articulate answer to the central question Forsythe poses in his essay: "What else, besides the body, might choreographic thinking look like?" ${ }^{\prime \prime}$ The film marks a step forward in the active curiosity of both artists: a progression from Hinton's previous archive-derived works such as Birds and Snow (the latter a collaboration with choreographer Rosemary Lee), and a progression of Davies' long-standing interest in the choreographic possibilities of everyday movement.

According to Davies, when she told Hinton she would like to take the seemingly simple activity of walking as the impetus for their collaboration-the orchestration of "this massive amount of information-probably about one thousand activities in the body which allow us to walk"7 - Hinton's reply was that this sounded very boring. ${ }^{8}$ Hinton recalls that his immediate instinct was to "dramatize the walk." 
For Hinton, as is evident in his other works, the grammar of film demands some form of narrative structure.

In watching All This Can Happen, it is fascinating to see these two sensibilities at work: the interplay of orchestration and dramatization as organizing principles bringing together contrasting cinematic conventions and histories. As art theorist and curator Laura U. Marks has observed:

In its early years cinema appealed to the emerging fascination with the instability of vision, to embodied vision and the viewer's physiological responses.... [But] As the language of cinema became standardized, cinema appealed more to narrative identification than to body identification. $^{10}$

All This Can Happen stands somewhere between these two positions, questioning the ways we perceive and formulate meaning. Burrows' suggestion of choreography as a "continuity of connection between materials" seems particularly apposite in positioning this film's questioning and construction of meaning as a choreographic endeavor.

\section{A lasting impression}

That dance is ephemeral is a given, being here and then gone; film disintegrates more slowly, allowing us to reflect upon it in a more leisurely way, but disappear it does. All This Can Happen foregrounds this slower but no less sure disappearance in two ways. Firstly, there is the use of images where the process of decay is already apparent-the saturation of color fading, the appearance of texture through the degradation of the fabric of the image. Secondly, there is the creative reuse of images to tell stories other than their own, and stills reframed as movement. What All This Can Happen demonstrates is that film's existence is finite but not final.

Writing of perspectives on time and place in her book For Space, geographer Doreen Massey describes a moment when her "imagination was reworked." ${ }^{11}$ She was in Keswick in England's Lake District, thinking about history and how the town had changed: considering that, over all the human activities the traces of which remained in the town from Roman times to the present day, there had presided Skiddaw: "a massive block of a mountain ... high, grey, and stony ... impressive, immovable, timeless." ${ }^{12}$ Her reworking of imagination, as she describes it, was her realization that the nearby Skiddaw was itself not as permanent as it might appear. Its rocks were shaped rather by shifting coastlines, eroding ancient lands and volcanic activity over many centuries: "A long and turbulent history, then. So much for timelessness."13 And as Massey observes, as history continues to unfold, so the mountains continue to move: at the rate of a couple of centimeters a year, she writes: "about the rate at which our fingernails grow."14 
My impression of watching All This Can Happen is that a similarly simple but irrevocable reworking of imagination is at play: a shift in realization around choreography, photography, film, and the passage of time. Davies' and Hinton's film is imbued with the ephemeral quality usually accorded to performance-ungraspable in its complexity, leaving a lingering impression of form, patterning, strata, sensation. Although structured in response to narrative, the overall experience of watching is of moving beyond words.

There is something in Massey's translation of the rate of tectonic shifts (moving mountains) to a human scale (the growth rate of fingernails) that seems fitting in discussing All This Can Happen as a work that shapes an almost unfeasibly large archival scope into the narrative of a day in the life of one person; as one reviewer, Sukhev Sandu, describes it, the film is "both harrowing and full of levity, pathological and poignant, microscopic and expansive." ${ }^{15}$ And crucially, as another reviewer, Sanjoy Roy, notes, "all this did happen"16 -all of the material is drawn from documentary film and photography, contexts then fused together, meanings rearranged, images repurposed to illustrate and illuminate Walser's story and, more widely, something of the human experience of moving.

All This Can Happen offers rich material for considering the convergence and fragmentation of photography and film media-from what did happen, through what can happen, to what might happen next-questioning the nature of these forms while also questioning what choreography might be or do. To draw on Heidegger's famous essay on technology, this film is concerned more with "catching sight of what comes to presence in technology [than] of merely staring at the technological. ${ }^{117}$ What comes to presence for me through All This Can Happen is an exhilarating torrent of information about the world, a wealth of imagery that leaves me marveling, and a sense of cautious excitement as to what might happen next.

\section{Notes}

1. Siobhan Davies, talk given by the artist to introduce a screening of $A / l$ This Can Happen at Arnolfini (Bristol, UK: 2013).

2. Miranda Pennell, "Some thoughts on nowness and thenness," The International Journal of Screendance 2 (Spring 2012): 72.

3. Ibid.

4. William Forsythe, Choreographic Objects, n.d., accessed May 1, 2014, http://www.williamforsythe.de/essay.html. 
5. Jonathan Burrows, A Choreographer's Handbook (Abingdon and New York: Routledge, 2010), 24.

6. Forsythe. Choreographic Objects.

7. Claudia Kappenberg and Sarah Whatley, "A Report on the Screendance Symposium, University of Brighton, Februrary 4, 2011," The International Journal of Screendance 2 (Spring 2012): 144.

8. Davies, talk at Arnolfini.

9. Kappenberg and Whatley, "A Report ," 144.

10. Laura U. Marks, Touch: Sensuous Theory and Multisensory Media (Minneapolis: University of Minnesota Press, 2002), 7.

11. Doreen Massey, For Space (London: Sage, 2005), 131.

12. Ibid.

13. Ibid., 133.

14. Ibid., 137.

15. Sukhev Sandu, "The Mighty Walser," Sight \& Sound 23, no. 12 (December 2013): 56.

16. Sanjoy Roy, "Review of All This Can Happen," Aesthetica Blog, n.d., http://www.aestheticamagazine.com/blog/review-of-all-this-can-happen-by-siobhandavies-and-david-hinton/.

17. Martin Heidegger, The Question Concerning Technology and Other Essays, translated by William Lovitt (New York: Garland Publishing, Inc., 1954, 1977 ed.), 32.

\section{References}

Burrows, Jonathan. A Choreographer's Handbook. Abingdon and New York:

Routledge, 2010.

Davies, Siobhan. Talk given by the artist to introduce a screening of All This Can Happen at Arnolfini. Bristol, UK, 2013.

Forsythe, William. Choreographic Objects. No date. Accessed May 1, 2014. http://www.williamforsythe.de/essay.html.

Heidegger, Martin. The Question Concerning Technology and Other Essays. Translated by William Lovitt. New York and London: Garland Publishing, Inc., 1954 (1977 ed.) 
Kappenberg, Claudia and Sarah Whatley. "A Report on the Screendance Symposium, University of Brighton, Februrary 4, 2011." The International Journal of Screendance 2 (Spring 2012): 140-152.

Marks, Laura U. Touch: Sensuous Theory and Multisensory Media. Minneapolis/ London: University of Minnesota Press, 2002.

Massey, Doreen. For Space. London: Sage, 2005.

Pennell, Miranda. "Some Thoughts on Nowness and Thenness." The International Journal of Screendance 2 (Spring 2012): 72-77.

Roy, Sanjoy . "Review of All This Can Happen." Aesthetica Blog. No date. http://www.aestheticamagazine.com/blog/review-of-all-this-can-happen-by-siobhandavies-and-david-hinton/.

Sandu, Sukhev. "The Mighty Walser." Sight \& Sound 23, no. 12 (December 2013): 56. 